\title{
FORMATION OF INVESTMENT POTENTIAL AS A FACTOR IN THE DEVELOPMENT OF IVANO-FRANKIVSK UTC
}

\author{
ANTONINA TOMASHEVSKA
}

Abstract. One of the key tasks of the current government is to develop the regions and strengthen their economic potential. One of the most important factors of economic growth is investment. For Ukraine, which is in a crisis pit, the issue of attracting foreign investments is especially important and relevant, as they have a significant impact on the economic development of the country. At the same time, the largest degradation in Ukraine today is investment activity, which is also due to the outbreak of COVID-19. Deterioration of the investment climate, the possibilities of budgets at all levels, the decline in business activity of economic entities have led to a difficult state of the investment sphere.

The article analyzes the investment attractiveness of the regions of Ukraine. A special role is focused on the factors (positive and negative) that affect the formation of the investment climate of the regions: positive - geographical location, labor resources; negative - unfavorable climate and corruption.

One of the indicators that reflects the stable economic development of certain sectors of the economy, as well as the country's economy as a whole is the investment potential of the regions. The investment and foreign economic policy of Ivano-Frankivsk UTC is analyzed, which is aimed at improving the image at the regional and international levels, promoting a significant increase in domestic and foreign investment in economic development, the implementation of active information and promotional activities.

In the city, foreign investment is about 580 million dollars. US dollars, of which almost 80 million dollars. USA - loan capital. During the study, we analyzed the largest enterprises in IvanoFrankivsk, including foreign investment, LLC "Electrolux Ukraine", LLC "Tyco Electronics Ukraine Limited", SE VO “Karpaty" (Delphi project), LLC “Imperial Foods”.

The method of expert assessments indicates promising areas of business development of IvanoFrankivsk UTC. In the course of the research we suggested ways to improve the investment attractiveness of Ivano-Frankivsk UTC.

Keywords: investment potential, investment attractiveness of the region, UTC.

JEL Classification: J5, Q12 


\section{INTRODUCTION}

Investment potential is the main condition for the formation of the investment climate in the region. In modern science, much attention is paid to the study of the essence of the investment potential of the region, in general, domestic economists do not have a specific understanding of the essence of the "investment potential of the region" of a single position on the interpretation of this complex economic category.

In scientific works we often see attempts of some authors to define the investment potential of the region as "compliance of the region with the main goals of investors, which are profitability, risk-free and liquidity of investments" [11]; "The level of satisfaction of financial, production, organizational and other requirements or interests of the investor in a particular region" [12]. A. Asaul in his work gives the following definition: "the position of the region at one time or another, the trends of its development are reflected in investment activity" [1]. Ya. Zadorozhna and L. Dyachenko consider investment potential not only as a financial and economic indicator, but also as a model of quantitative and qualitative indicators - assessments of the external environment (political, economic, social, legal) and internal positioning of the object in the external environment [4].

\section{THEORETICAL BACKGROUND}

Research of the problem and study of the investment potential of the regions of Ukraine today becomes especially relevant. Theoretical and practical aspects of the investment potential of the regions were devoted to a significant number of works by leading domestic and foreign researchers, among them: O. Vlasyuk, O. Gavrilyuk, B. Gubansky, I. Dragan, G. Kalach, I. Blank. However, many problems of theoretical and practical nature in this area remain unresolved, which necessitates additional research to improve the investment potential of the regions.

\section{Research Objective, Methodology and Data}

The purpose of scientific work is theoretical substantiation, development of scientific and methodical bases and practical offers which are directed on increase of investment potential of IvanoFrankivsk UTC.

In accordance with the goal in the work were identified and solved the following tasks:

- to reveal theoretical essence and feature investment potential;

- analyze the mechanisms for calculating the investment potential of the region;

- identify the main problems associated with the inflow of investment into the economy of IvanoFrankivsk;

- identify ways to increase the investment attractiveness of Ivano-Frankivsk UTC.

Object of study: realization of investment potential of the region.

Subject research: theoretical and methodological and practical recommendations for increasing the investment potential of the region.

To achieve the goal and solve the main problems of scientific work, various research methods are used. The main general scientific research methods used by the author include: dialectical method of cognition; logical and formal-logical methods; method of comparison, generalization, systematization and synthesis (in the study of the theoretical essence of investment attractiveness); grouping, statistical, mathematical, graphical analysis (in the analysis of indicators of investment attractiveness); systemic and integrated approaches (in developing recommendations and improving the mechanism for increasing the investment potential of the region). 


\section{RESUlTS AND DisCUSSION}

The outbreak of COVID-19 worldwide has largely led to a sharp decline in the value of financial assets. Despite some recovery in quotations at the end of the year, uncertainty remains extremely high. Regulators around the world have to deal with the consequences for the economy, and perhaps the main challenge is to coordinate the actions of monetary and fiscal authorities to prevent a liquidity crisis in the financial system.

Unfortunately, at present, no noticeable progress is seen against the background of the Ukrainian economic path (except for a short period, which our people chose after the Orange Revolution). For the whole of 2019, the total direct investment did not exceed 2 billion US dollars, and this figure decreased significantly compared to 2018. In addition, the vast majority of capital comes from jurisdictions such as Cyprus and the Netherlands, which in many cases is a transfer of money from the "offshore wallets" of Ukrainian business and can hardly be considered a real entry into the Ukrainian market of new foreign capital.

The investment potential of a particular region is formed under the influence of factors at the national and regional levels. National-level programs characterize the country's investment environment as a whole, and regional programs are specific to a particular city or region. In turn, among these factors are positive and negative.

Geographical location, labor resources, natural resources are positive regional factors that have a significant impact on the investment potential of the region. Unfavorable climate and corruption are negative regional factors that harm the investment environment of the region.

Ranking of regions according to the investment attractiveness index 2019 shown in Fig. 1.

According to A. Duka, the investment attractiveness of the country is determined by the following factors [5]:

- opportunity to gain a foothold in the promising market of Ukraine;

- the desire to make a profit on a long-term basis;

- access to relatively cheap sources of raw materials and resources, which increases the competitiveness of products by saving production costs and proximity to sources of raw materials;

- the use of relatively cheap and skilled labor as an important factor in reducing production costs and, accordingly, the cost of production.

Ivano-Frankivsk is one of the famous economic, cultural and industrial centers of Western Ukraine. The good geographical location of the city creates favorable conditions for multilateral development and European integration. For promoting European values, Ivano-Frankivsk received all four high awards of the Parliamentary Assembly of the Council of Europe - the European Diploma, the Honorary Flag, the Badge of Honor and the European Prize.

As you know, 2020, when the law on administrative and territorial organization enters into force, should be the year of completion of the program of community unification in Ukraine. The reform program is currently far behind the government's schedule and is unlikely by the end of 2020. the entire territory of Ukraine will be covered by UTC, as planned at the beginning of the reform. Therefore, various surprises are possible up to the centralized unification of small UTCs into larger ones. R. Panasyuk, Director of the Ivano-Frankivsk Center for Local Self-Government Development, rightly notes in this regard that there are also communities near Ivano-Frankivsk that are not provided for in the Perspective Plan for the Formation of Territories of Communities in the Region. The format in which they are now (only two entities in the union, the need for subsidies, a small area, proximity to Ivano-Frankivsk), may result in that these UTCs will not remain on the administrative map at all. Of the three possible options for them, R. Panasyuk calls joining Ivano-Frankivsk the "most logical" [14]. 


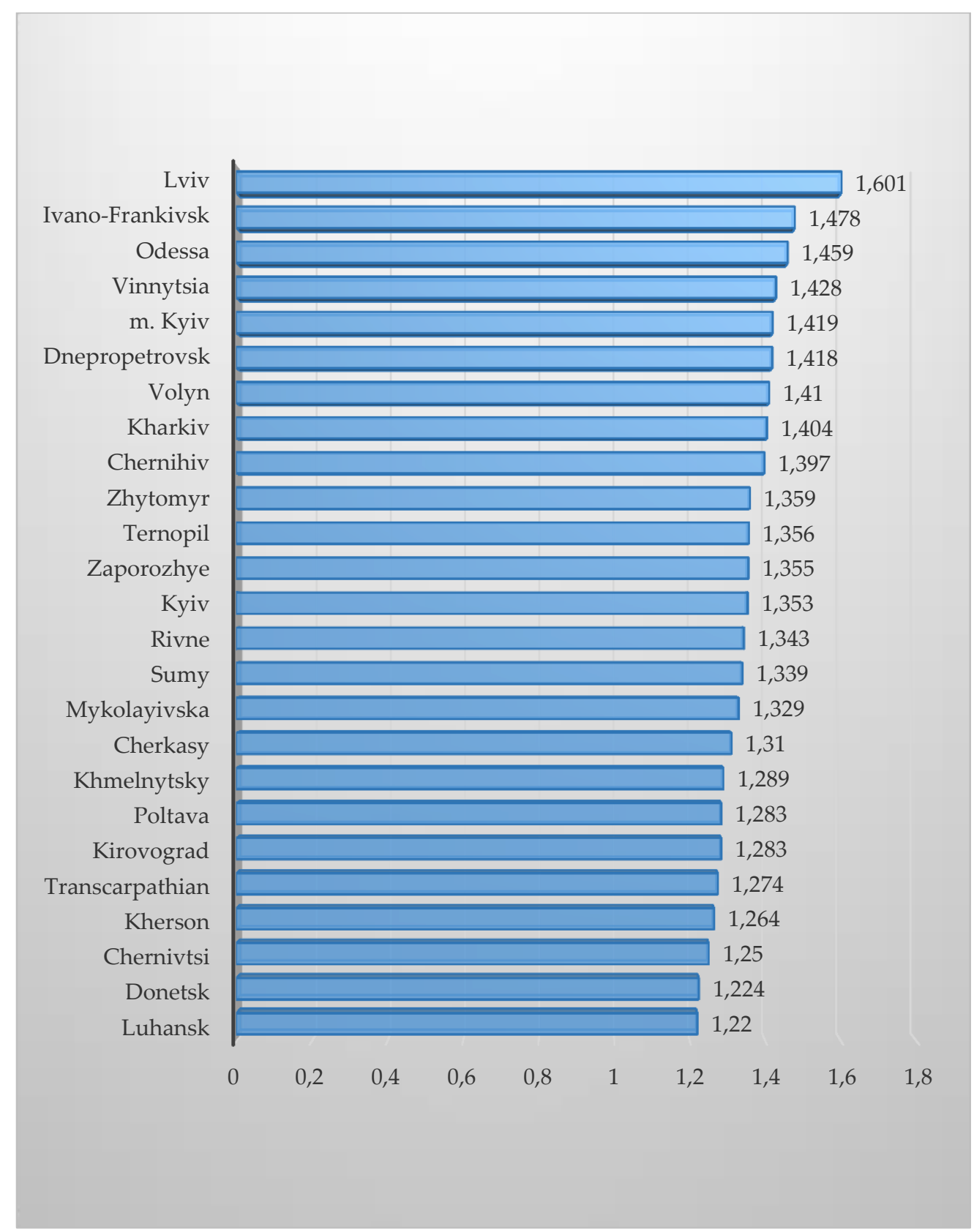

Fig. 1. Index of investment attractiveness of regions, 2019. Source: [12].

This opinion is confirmed by the conclusion of experts from the Swedish consulting company SKL International, which implements the Swedish-Ukrainian project "Support to Decentralization in Ukraine", and the U-LEAD with Europe Program. Experts based on the analysis of budget execution of 806 UTCs in Ukraine in January-June this year expressed the opinion that one of the best options for further development for communities with low financial capacity is to join other territorial communities and create a larger area and number of UTCs. Even if such an UTC does not yet have economic prospects for development, such an association will make it possible to optimize the territorial structure of local councils and increase the efficiency of their management and improve investment attractiveness through more territory and more manpower [14].

Among the advantages of Ivano-Frankivsk UTC are new investment zones for the city; larger funds of one of the instruments of state support for UTC development - infrastructure subvention, which the government distributes according to the formula according to the area of the community and the number of rural population, and therefore, the more rural areas united by the community, the larger the subvention; lands outside settlements that villages could not use on their own; reduction of the 
amount of reverse subsidy, which the city returns to the state budget; improvement of social services for villagers due to joining a financially viable city, etc.

The city of Ivano-Frankivsk has documented economic ties with 24 local governments abroad, including: Poland, Hungary, the Czech Republic, Moldova, Romania, Belarus, Lithuania, Latvia, the United States, Portugal, Georgia.

In Ivano-Frankivsk, about 20 international projects are being implemented under the programs of the European Union, the United Nations Development Program, the World Bank, the European Bank for Reconstruction and Development, and others.

Ivano-Frankivsk maintains investment attractiveness for investors, as evidenced by one of the highest rates of foreign investment per capita compared to the overall figure for Ukraine, which is almost 2 thousand US dollars. Foreign investors sent \$ 498.1 million to the development of IvanoFrankivsk. The United States, in particular, gives preference to enterprises in the processing industry and wholesale (92\%) (Fig. 2).

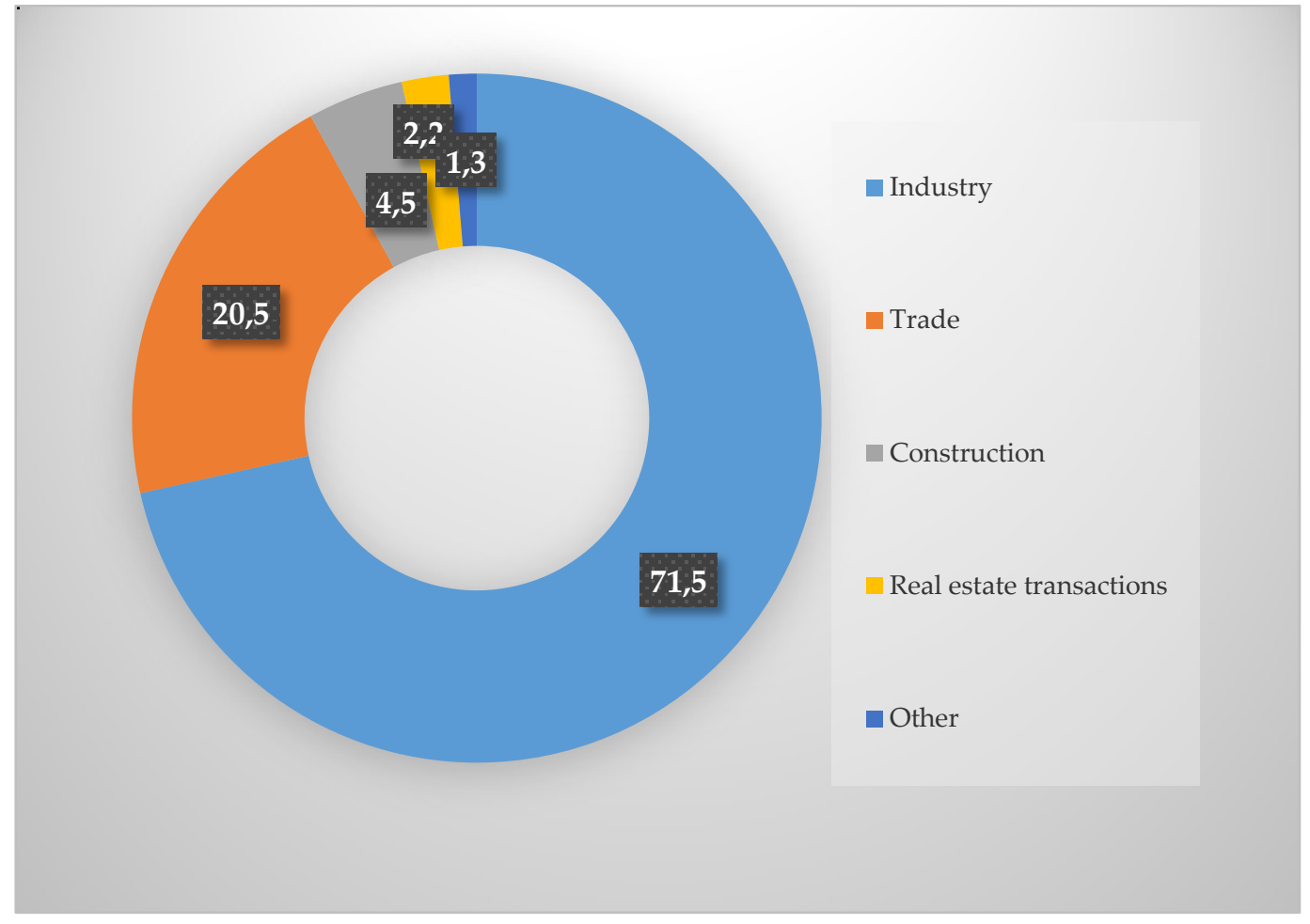

Fig.2. Structure of foreign direct investment in the economy of Ivano-Frankivsk.

Source: compiled by the author based on [12].

Ivano-Frankivsk enterprises are actively engaged in foreign economic activity with 90 countries. The main export sectors of the city's economy are machine-building, food and chemical industries, which account for $89 \%$ of urban exports. Thus, in 2019, Ivano-Frankivsk enterprises exported products worth \$ 252.7 million. US dollars, and imported 232.4 million dollars. USA (Fig. 3). 


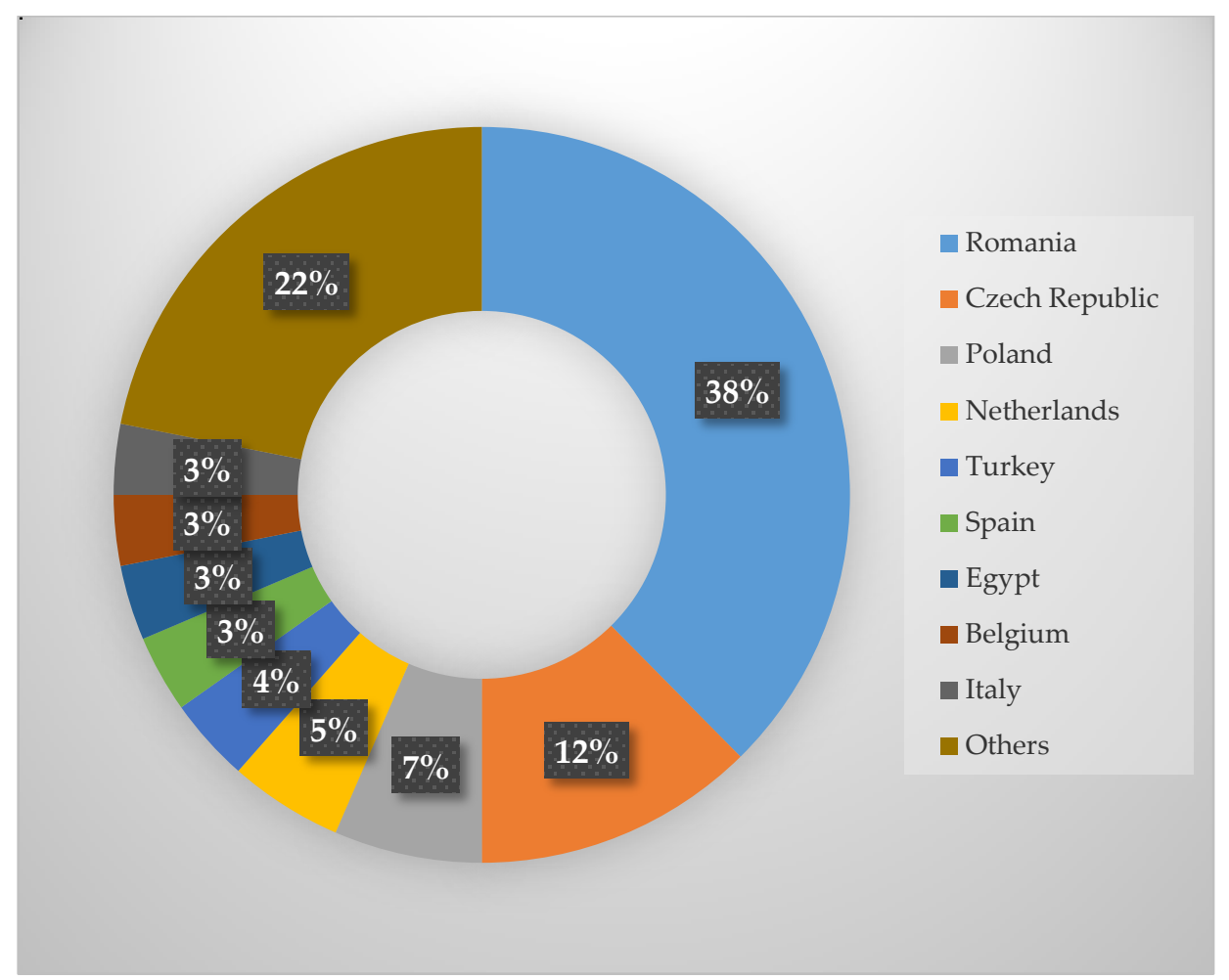

Fig. 3. The largest expert deliveries are in Ivano-Frankivsk. Source: compiled by the author based on [12].

First place in the ranking of transparency for investment in 2019. took the city of Ivano-Frankivsk, the second - Kiev, the third took the city of Vinnytsia. The Ukrainian office of the international anticorruption network Transparency International has created transparency rating_investment sphere of the hundred largest cities of Ukraine. Analysts tested how each city informs potential investors about how to invest in the city, how open the rules of the game are for investors and entrepreneurs and whether it is convenient for them to start a business [10].

The level of investment potential of Ivano-Frankivsk is due to:

1) Favorable location: Ivano-Frankivsk is close to the borders and well located relative to transit routes, including international ones. The city's prospects are also related to the location near the Carpathians (region of tourism, recreation and recreation). The potential for the development of tourism, balneology is high. The ecological situation in the city is good compared to other regions;

2) The city has the necessary infrastructure for the operation of enterprises of various economic activities. Developed market infrastructure, a network of financial institutions, educational, health and cultural institutions create a high quality of life compared to other regions and contribute to the mechanical growth of the population.

3) The labor market of the city is sufficiently provided with highly qualified labor resources. Improving scientific and human resources is provided by a wide network of higher and secondary special educational institutions that train specialists in various professions. The relatively low level of wages creates additional benefits for investors in terms of labor costs. Much of the population is quite mobile and employed in small and medium-sized businesses;

4) Developed communication infrastructure and good transport links. The city is a logistics center of the south-western region of Ukraine, has an extensive transport infrastructure and capacity for freight and passenger traffic; availability of access railways to enterprises, good condition of highways, operating international airport;

5) An acceptable level of development of communal infrastructure. However, it should be noted the need for major repairs of engineering infrastructure due to its deterioration, which is typical for most cities of Ukraine. At the same time, the city authorities are actively working to attract investment to improve the city's infrastructure; 
6) Multisectoral specialization of industry, which provides relative resilience to fluctuations in the economic situation in the country. The city is developing its traditional branches of food, machinebuilding, woodworking industries, in which significant amounts of foreign investment have already been attracted. Multisectoral specialization of the city allows to carry out complex investment projects on the terms of economic cooperation;

7) Openness of local authorities to work with foreign and domestic investors, availability of preferences for investors, transparent administrative procedures, comprehensive support of investment projects. The city authorities have successful experience working with large foreign investors and international financial institutions. The rating agency believes that the degree of information transparency of the activities and activity of the city authorities is at a very high level. The activities of the government are aimed at the economic development of the city through partnership processes, creating conditions for long-term development, popularization of the city.

Ranking of factors of investment potential of Ivano-Frankivsk UTC is shown in Fig. 4.

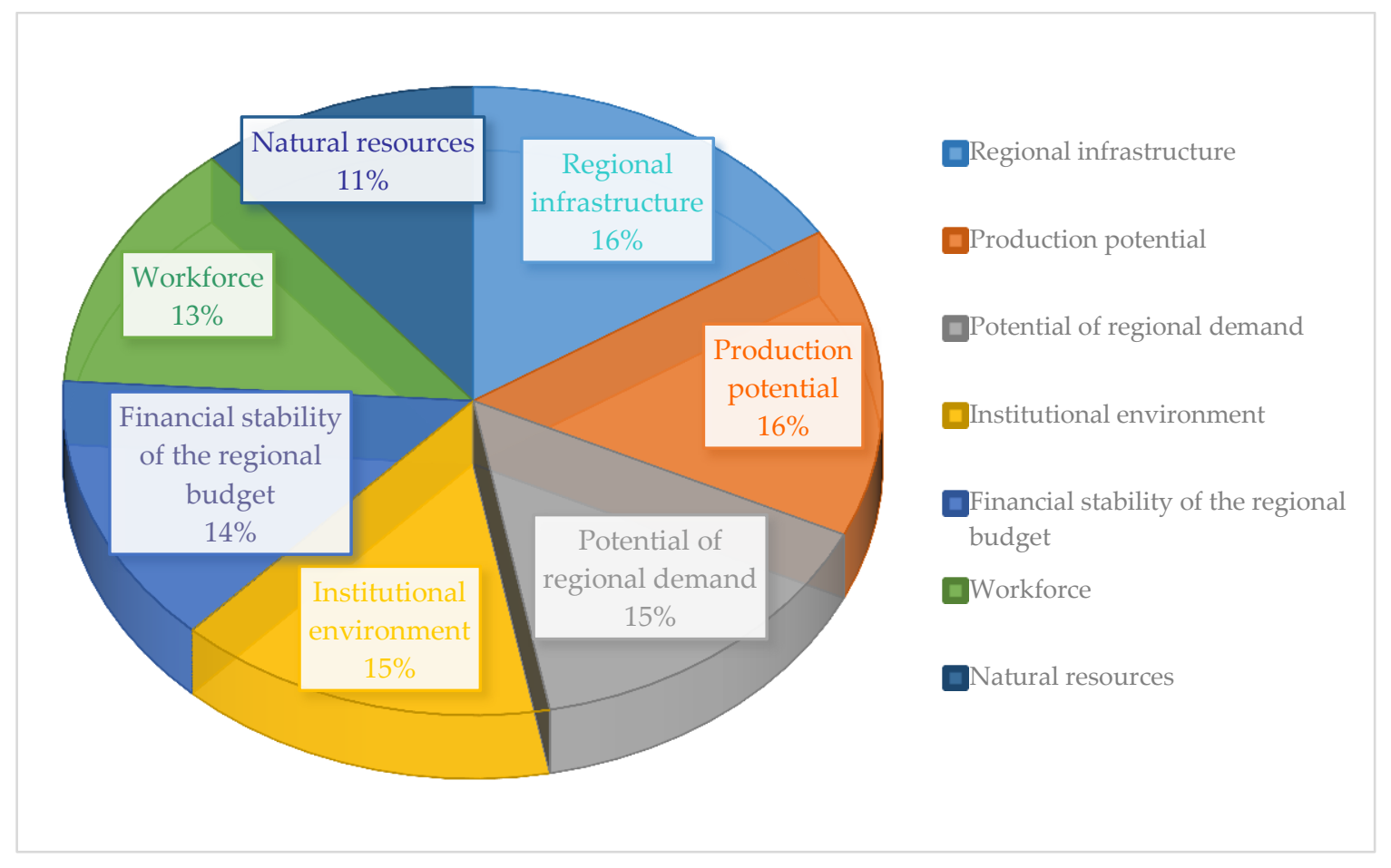

Fig.4. Ranking of factors of investment potential of Ivano-Frankivsk UTC. Source: compiled by the author based on his own research

The results of the assessment of the influence of various external factors on the investment attractiveness of Ivano-Frankivsk are generalized UTC are shown in Fig. 5. 


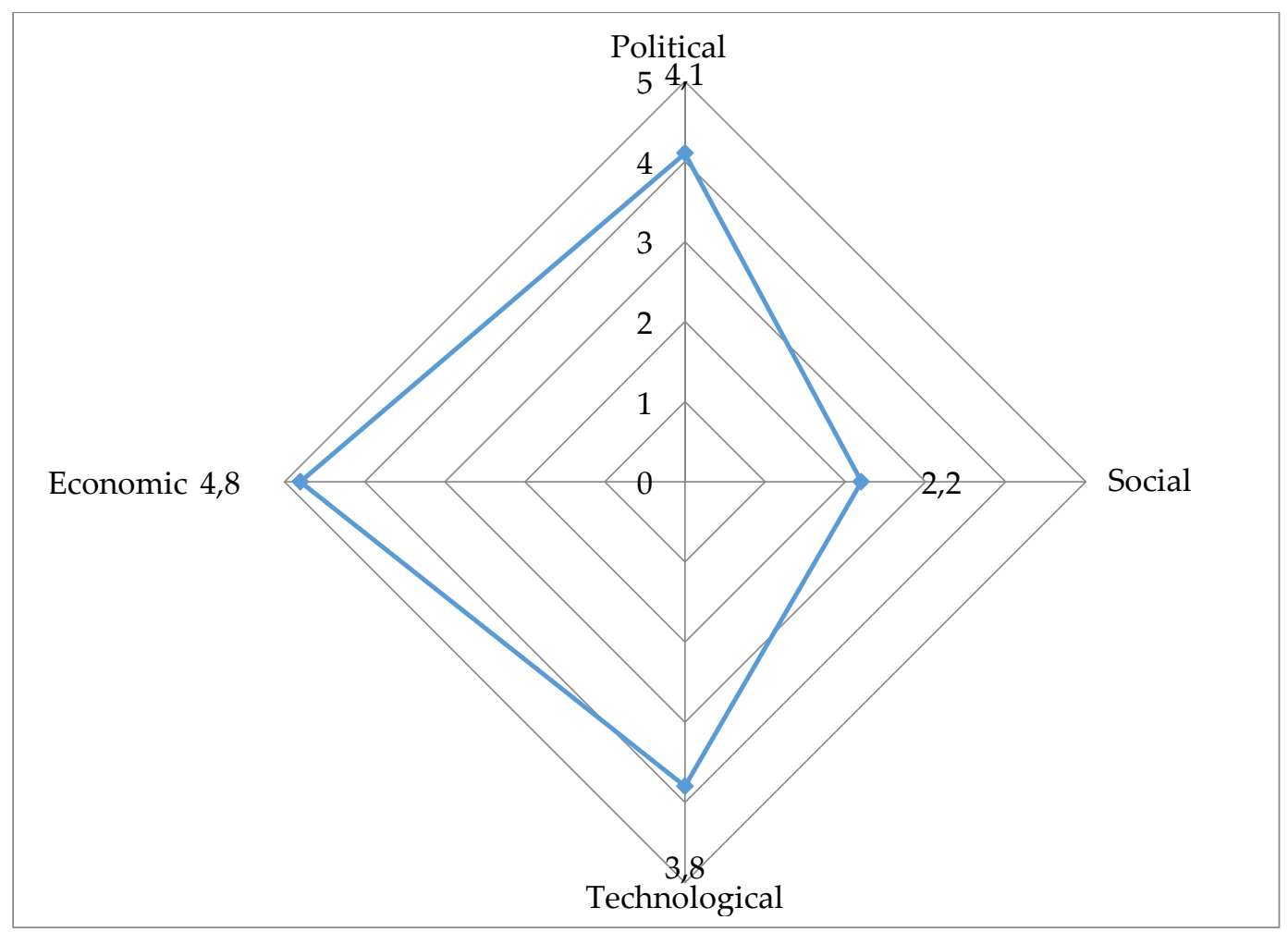

Fig. 5. Assessment of the impact of factors on the investment potential of Ivano-Frankivsk UTC.

Source: compiled by the author based on his own research.

During our research, a secret survey was conducted among 277 entrepreneurs and potential investors.

Issues that were addressed:

1. Name the most expected steps by the authorities for the development of entrepreneurship in Ivano-Frankivsk. In general, most noted the following problems:

- development of general infrastructure - 93\%;

- improvement of services for entrepreneurs (especially electronic) - 92\%;

- investment attraction - 89\%;

- transparency in the management of communal property - 88\%;

- transparency in land management - 86\%;

- creation of service centers for entrepreneurs - $84 \%$;

- improvement of access to information - 83\%.

2. Among the biggest problems that hinder the work of entrepreneurs called:

- general economic situation - $66 \%$;

- internal competition - $47 \%$;

- energy costs - 27\%;

- lack of skilled labor - $24 \%$;

- lack of available funding - $18 \%$.

3. Entrepreneurs were also asked to indicate promising areas of business in the city (Fig. 6) 


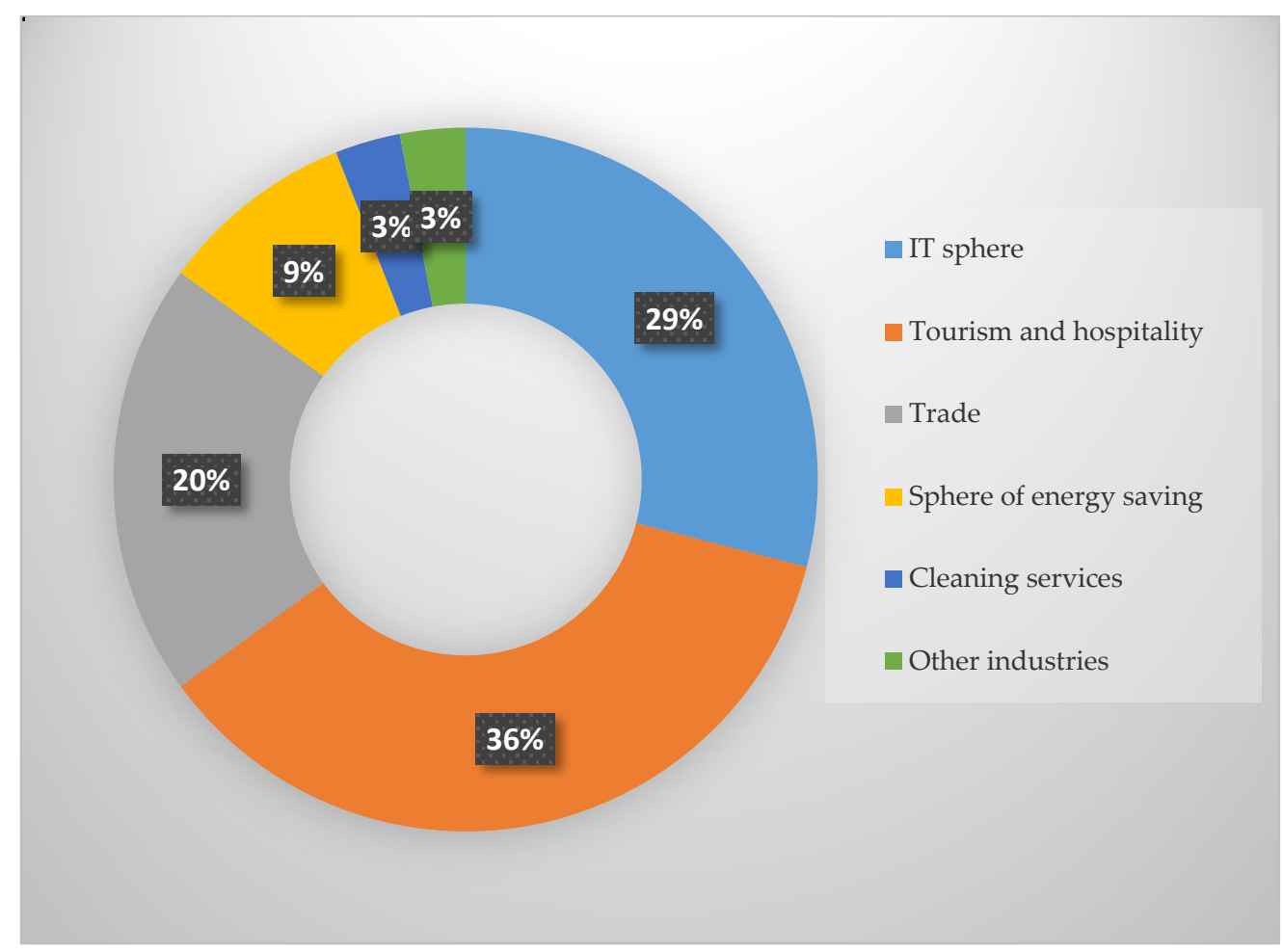

Fig. 6. Prospects for business development in Ivano-Frankivsk.

Source: compiled by the author based on his own research.

The main problem for foreign investors, in our opinion, is the presence of a corruption component at all levels.

If there is a risk of loss of fixed assets due to non-transparency of the procedure or corruption in the judiciary, the investor is not interested in the project even in the positive moments:

1) payback of projects in Ukraine - short;

2) cheap labor compared to the same Poland, the Czech Republic, Slovenia, but this is not a significant part of operating costs, which is not so significantly affects profits.

\section{CONCLUSIONS}

In the city, foreign investment is about 580 million dollars. US dollars, of which almost 80 million dollars. USA - loan capital. In the course of the research we proposed the following ways to improve the investment attractiveness of Ivano-Frankivsk UTC, in particular:

- specification of investment priorities, investment entities, the amount of investment and socioeconomic consequences for the territory, the definition of entities and control mechanisms in the annual programs of socio-economic and cultural development of territories;

- constructive cooperation of local authorities with economic entities of the region (public-private partnership) and combining their efforts to attract an effective investor and achieve the desired concrete result;

- creation of an interactive map of the industry of Ivano-Frankivsk UTC (with a forecast analysis of the possibilities of promising areas of business, which were conducted in the study). 


\section{REFERENCES}

[1] Gaidutsky A.P. Estimation of investment attractiveness of economy. Economics and forecasting, 4 (2004), 119-129. Availablte at: http://eip.org.ua/?page_id=523\&aid=474 (in Ukrainian)

[2] The economy of the regions in 2018: new realities and opportunities in the context of reforms. NISD, Kyiv, 2018. Available at: http://old2.niss.gov.ua/content/articles/files/regionu-4adb9.pdf (in Ukrainian)

[3] Peresada A.A., Mayorova T.B., Onikienko S.V., Kovalenko Yu.M., Urvantseva S.V. Investment analysis. KNEU, Kyiv, 2008. (in Ukrainian)

[4] Osetsky V.L. Innovation and investment vector of socio-economic development: regional aspect. RFI scientific papers, 3 (2012), 183-185. Available at: http://nbuv.gov.ua/UJRN/Npndfi_2012_3_29 (in Ukrainian)

[5] Zavadsky G.M. Methodical approaches to assessing the investment attractiveness of the region. Global and national economic problems, 17 (2017), 152-155. Available at http://global-national.in.ua/archive/172017/34.pdf (in Ukrainian)

[6] Rating of investment attractiveness of regions. Inst. of Economic Research and Political Consultations. Available at:

http://www.ier.com.ua/files/Projects/2012/investment/Investment_Report_Long_version2013.pdf

[7] The official site of the State Statistics Committee of Ukraine. Available at: http://www.ukrstat.gov.ua (in Ukrainian)

[8] Official site of the rating agency "Euro-rating". Methodology of rating of cities and regions. Available at: http://euro-rating.com.ua/regiony/metodologiya/ (in Ukrainian)

[9] Official site of the rating agency "IBI Rating". Available at: http://ibi.com.ua/RU/ratings-list/ (in Ukrainian)

[10] International Center for Policy Studies. Regional business environment in Ukraine. Available at: http://competitiveness.icps.com.ua/ (in Ukrainian)

[11] Fedorenko V.G., Zakhozhai V.B., Chuvardinsky V.G. Insurance and investment management. MAUP, Kyiv, 2002. Available at: http://fingal.com.ua/content/view/1167/87/ (in Ukrainian)

[12] Official website of the city of Ivano-Frankivsk. Available at: www.mvk.if.ua (in Ukrainian)

Address: Antonina Tomashevska, Vasyl Stefanyk Precarpathian National University, 57 Shevchenko St., Ivano-Frankivsk, 76018 Ukraine.

E-mail: lianeta@i.ua

Received: August 8, 2020; revised: October 20, 2020.

Томашевська Антоніна. Формування інвестиційного потенціалу, як фактору розвитку ІваноФранківської ОТГ. Журнал Прикарпатського університету імені Василя Стефаника, 7 (3) (2020), 78-88.

Одним із ключових завдань нинішньої влади є питання розвитку регіонів та посилення їхнього економічного потенціалу. Одним з найважливіших чинників економічного зростання $є$ інвестиції. Для України, яка знаходиться в кризовій ямі, особливо важливим та актуальним є питання залучення іноземних інвестицій, оскільки вони мають вагомий впдив на економічний розвиток країни. Поряд 3 тим найбільшої деградації в Україні на сьогодні зазнає інвестиційна діяльність, яка зумовлена також і спалахом захворювання COVID-19. Погіршення інвестиційного клімату, можливостей бюджетів усіх рівнів, зниження ділової активності суб'єктів господарювання призвели до скдадного стану інвестиційної сфери.

У статті проаналізовано інвестиційну привабливість регіонів України. Особливу роль зосереджено на факторах (позитивних та негативних), які впливають на формування інвестиційного 
клімату регіонів: позитивні - географічне розташування, трудові ресурси; негативні - несприятливий клімат і корупція.

Одним із показників, що відображає стабільний економічний розвиток окремих галузей економіки, а також економіки країни загалом $є$ інвестиційний потенціал регіонів. Проаналізовано інвестиційну та зовнішньоекономічну політику Івано-Франківської ОТГ, яка спрямована на покращення іміджу на регіональному та міжнародному рівнях, сприяння істотному збільшенню надходжень внутрішніх і зовнішніх інвестицій у розвиток економіки, здійснення активної інформаційно-промоційної діяльності.

В місті іноземні інвестиції складають близько 580 млн дол. США, із них майже 80 млн дол. США - позичковий капітал. Під час дослідження нами було проаналізовано найбільші підприємства м.Івано-Франківськ, зокрема і з іноземними інвестиціями, ТОВ “Електролюкс Уукраїна“, ТОВ “Тайко Едектронікс Юкрейн Лімітед“, ДП ВО ,"Карпати“ (проєкт Делфі), ТОВ ”Імперово Фудз“.

Методом експертних оцінок зазначені перспективні напрями розвитку бізнесу ІваноФранківської ОТГ. В процесі дослідження нами запропоновано шияхи покращення інвестиційної привабливості Івано-Франківської ОТГ.

Кдючові слова: інвестиційний потенціал, інвестиційна привабливість регіону. 